\title{
An experimental study on the mechanical properties of cemented rock - tailings fill
}

\author{
L. Guo Beijing General Research Institute of Mining and Metallurgy, China \\ X. Yang Beijing General Research Institute of Mining and Metallurgy, China \\ L. Xie Beijing General Research Institute of Mining and Metallurgy, China
}

\begin{abstract}
This paper outlines an effective approach to making composite backfill using mine waste material. Composite materials are widely used in many areas of engineering because of their unique structural properties. Cemented rock-tailings are one of the most prevalent materials used for composite backfill because they can effectively make use of mine waste rock and mill tailings that would otherwise be simply considered waste. This backfill method has the capability of maintaining the mine environment while still allowing for continued mine development.

An experimental study is being conducted in a cooperative mine research project to investigate the properties of backfill material and specifically the mechanical characteristics of cemented waste rocktailings fill. This study details the characteristics of the composite backfill aggregate with respect to the compressive strength of the cemented rock-tailings fill and the backfill mix-proportion, as well as outlines a new method of study for cemented rock-tailings fill mechanics. The study results show the compressive strength of cemented rock-tailings fill is dependent mainly on the cement and waste rock content. Ensuring a precise backfill mix proportion can effectively reduce the cement dosage, thereby decreasing the backfill cost realised for the mine.
\end{abstract}

\section{Introduction}

The use of the cut-and-fill mining method continues to increase in importance for the mining industry worldwide (Kuganathan, 2005). One of the fills used in industrial practice is cemented rockfill (CRF). Cemented rockfill is comprised of large sized aggregates mixed with various types and amounts of binder materials (Hassani and Razavi, 2007). These materials have a technological advantage in the industry in that they are widely available materials which would normally only be considered waste (Annor, 1999).

Anqing Copper Mine's Study on CRF mechanical properties is the foundation of CRF technology. It covers studies on the CRF process and backfill mechanical characteristics. The present study on CRF investigates the basic mechanics of cemented rock-tailings filling, primarily the physical and mechanical characteristics of waste rock and tailings, computing and determining the functional relation of CRF strength and influencing factors. The mechanical intensity law and the extent of the influence of cemented rock-tailings filling on interrelated factors are revealed to provide an important reference for the optimum design of the mix proportions of CRF material.

\section{Aggregate properties of cemented waste rock-tailings fill}

Cemented waste rock-tailings fill materials consist of fill aggregates and cementitious materials. Filling aggregates generally include mine waste rock and classified tailings; cementitious materials are usually normal or ordinary Portland cement. The aggregate properties of cemented rock-tailings filling directly affect the quality of the mine-filling body and filling cost.

Experiments were conducted to study the cemented waste rock-tailings filling of Anqing Copper Mine in China. The tailings and waste rock aggregates were both from the mine; the tailings were mine-classified tailings and the waste rocky materials were marbles and diorites from the waste of underground 
development. The physical, chemical and mechanical properties were determined in tests that provide the basis for the mechanics experiments on cemented waste rock-tailings filling.

\subsection{Basic characteristics of tailings}

The basic characteristics of tailings are their physical properties (volume weight, density, porosity and permeability coefficient), chemical properties (mineral composition) and sizes. The physical properties of the tailings are given in Table 1.

Table 1 Physical parameters of tailings

\begin{tabular}{llllll}
\hline $\begin{array}{l}\text { Year of } \\
\text { Tailings }\end{array}$ & $\begin{array}{l}\text { Density } \\
\left(\mathbf{g} / \mathbf{c m}^{\mathbf{3}}\right)\end{array}$ & $\begin{array}{l}\text { Volume } \\
\text { Weight } \\
\left(\mathbf{g} / \mathbf{c m}^{3}\right)\end{array}$ & $\begin{array}{l}\text { Porosity } \\
(\mathbf{\%})\end{array}$ & \multicolumn{2}{l}{$\begin{array}{l}\text { Permeability } \\
\text { Coefficient } \mathbf{( c m} / \mathbf{h})\end{array}$} \\
\hline 1992 & 3.43 & 1.84 & 46.36 & 17.30 & -- \\
2004 & 3.390 & 1.781 & 47.46 & 5.9 & 8.7 \\
\hline
\end{tabular}

In Table 1, there are no significant differences in the density, unit weight and porosity of the tailings of 1992 and 2004, but the permeability coefficient was much greater in 1992.

The chemical compositions of tailings have a certain influence on the physical properties and cementing performance of the filling materials, and the effect of the sulfide content on the performance of the cemented fill body is considerable.

Chemical analysis showed that tailings mainly comprised $\mathrm{SiO}_{2}, \mathrm{CaO}$, TFe and small amounts of $\mathrm{Al}_{2} \mathrm{O}_{3}, \mathrm{MgO}$, $\mathrm{Ag}$ and $\mathrm{Cu}$. Moreover, trace amounts of harmful substances such as $\mathrm{S}$ and sulfide, which had little influence on the strength of cemented fill body, were present.

The size fraction distribution of tailings greatly affects the cemented fill body, especially the permeability capacity of the filling slurry, porosity of the cementation body and pore size distribution. Fine grains (that would pass through a $200 \mathrm{mesh} /$ inch sieve) accounted for $42 \%$ of the investigated tailings, and the mediangrain size $\mathrm{d}_{50}$ and weighted average grain size were 0.097 and $0.127 \mathrm{~mm}$ respectively.

\subsection{Basic characteristics of waste rock}

The determination of the basic characteristic parameters of waste rock included measurements of the physical and chemical properties and sizing fraction of the rock. The physical and chemical properties of waste rock are listed in Table 2.

Table 2 Physical and chemical properties parameters of waste rock

\begin{tabular}{lllllll}
\hline $\begin{array}{l}\text { Waste Rock } \\
\text { Material }\end{array}$ & $\begin{array}{l}\text { Loose Bulk } \\
\text { Density } \\
\left(\mathbf{g} / \mathbf{c m}^{\mathbf{3}}\right)\end{array}$ & $\begin{array}{l}\text { Compacted } \\
\text { Bulk Density } \\
\left(\mathbf{g} / \mathbf{c m}^{3}\right)\end{array}$ & $\begin{array}{l}\text { Void Rate } \\
\mathbf{( \% )}\end{array}$ & $\begin{array}{l}\text { Mud Content } \\
\mathbf{( \% )}\end{array}$ & $\begin{array}{l}\text { Alkali-Silica } \\
\text { Aggregate } \\
\text { Reactions 14 d } \\
\text { Expansion } \\
\text { Ratio (\%) }\end{array}$ & $\begin{array}{l}\text { Sulfide- } \\
\text { Sulfate } \\
\text { Content (\%) }\end{array}$ \\
\hline Marble & 1.887 & 2.202 & 36.38 & 5.1 & 0.083 & 0.20 \\
Diorite & 1.543 & 1.895 & 44.71 & 3.1 & 0.022 & 0.36 \\
\hline
\end{tabular}

According to the criterion for alkali-silica aggregate reactions, there was no potential hazard of alkali-silica reaction for the marbles and diorites, and the sulfide and sulfate of waste rock aggregates had little influence on the potential chemical properties, chemical reactions and strength of fill.

A multiple stage screening method was adopted to determine the sizes of waste rock particles, and the size distribution is presented in Figure 1. The figure shows that the proportion of fine-grain gravels was greater for waste rock aggregates, with the fraction of particles smaller than $10 \mathrm{~mm}$ accounting for more than $15 \%$ of 
the waste rock. Therefore, it should be noted that fine grain gravels and fine mud in excavated waste rock influence the strength of the cementation body in the cement filling experiments. The weighted average particle sizes of marbles and diorites in waste rock materials were 95.35 and $143.42 \mathrm{~mm}$, respectively.

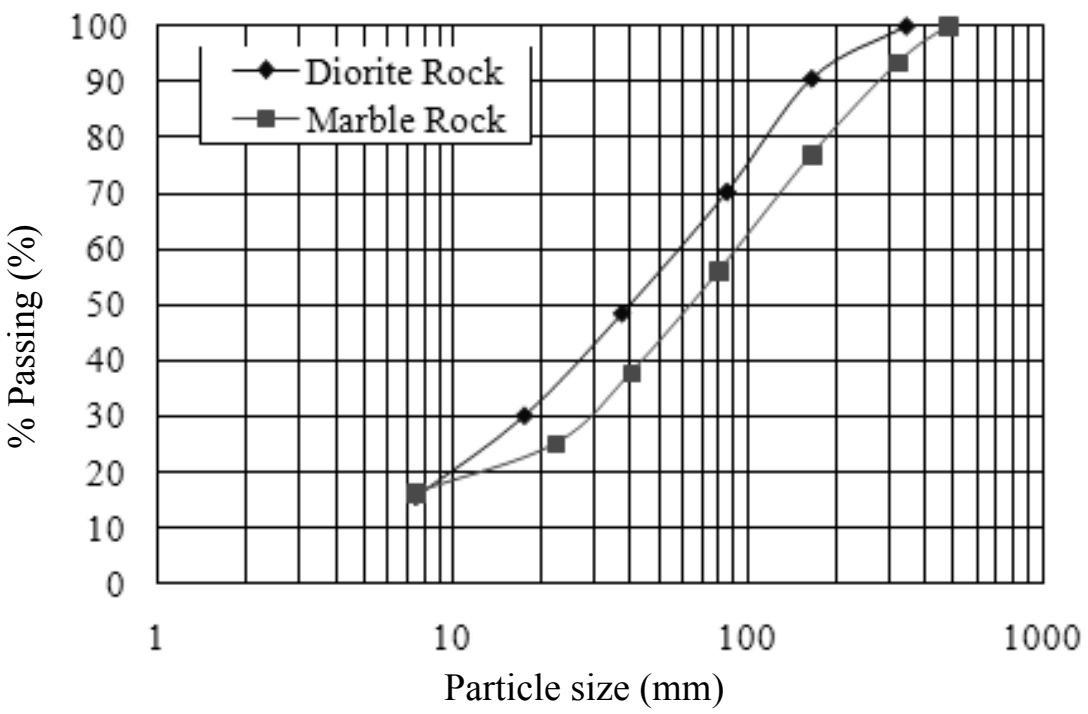

Figure 1 Particle size distribution of waste rock

\section{Mix proportion for cemented rock-tailings fill}

Experiments on the mix proportions for cemented rock-tailings filling were conducted in the laboratory to find the optimal aggregate proportion under the requirement of the strength of the cemented filling body and determine the mechanical parameters of the filling body. The experiment results were then used to determine the parameters of the cemented rock-tailings filling and evaluate the stability of the filling.

Different mix proportion tests were conducted for waste rock, tailings, cement and water to study the variation in properties and strength principle of the cemented waste rock-tailings filling body. The main tests were of the influences of the waste rock and cement and the mixed casting method.

The mix proportion parameters considered were the slurry concentration (the concentration of the cemented slurry comprising cement, tailings and water), water-cement weight ratio and the tailings-cement dry weight ratio. Mine filling is usually discussed in terms of the cement-tailings ratio, which is the reciprocal of the tailings-cement ratio; however, to facilitate analysis, the tailings-cement ratio was adopted in this study. In addition, we refer to the waste rock-tailings ratio, which is the weight ratio of waste rock to tailings among filling aggregates, the cement content, which is the dry-weight cement proportion of the filling material, and the waste rock content, which is the dry-weight waste rock proportion of the filling aggregate.

\subsection{Tests for influence on backfill strength}

Various influences on the backfill strength were investigated, including the type of waste rock type and the presence of muddy waste rock, were investigated.

\subsubsection{Test for backfill strength with varying waste rock}

\subsubsection{Design of experiment parameters}

Experiment design parameters were a cement content of $6 \%$, a slurry concentration of $72 \%$, and curing time of 28 days. The types of waste rock investigated were marbles and diorites. The waste rock-tailings ratios were $85 / 15 \%, 80 / 20 \%, 70 / 30 \%, 60 / 40 \%, 50 / 50 \%, 30 / 70 \%$ and $0 / 100 \%$. The test indicator was the unconfined compressive strength. 


\subsubsection{Experiment materials and methods}

The materials in the experiment were cement, waste rock, tailings and water. Grade 32.5 ordinary Portland cement was selected for mine filling. The waste rock had the natural gradation for underground excavation, excluding particles larger than $50 \mathrm{~mm}$. Classified tailings used in mine-filling with a water content of 5-10\% and $\mathrm{pH}$ of 7-9 were selected. Industrial water used in mine filling with a $\mathrm{pH}$ of 8-11 was selected. All experiment materials were within these ranges to guarantee test consistency and comparability.

The cylinder samples selected for experiments had a diameter of $152 \mathrm{~mm}$ and a height-diameter ratio of 2 . The test samples were cured for $28 \mathrm{~d}$ at a relative humidity greater than $92 \%$ and a temperature of $\left(20 \pm 2{ }^{\circ} \mathrm{C}\right)$, and their compressive strengths were then measured.

\subsubsection{Results and discussions}

Experiment results for the aggregates of waste rocks (marbles and diorites) and tailings under seven conditions, in addition to the conditions of invariable cement content and slurry concentration, are shown in Table 3 .

Table 3 Experiment results for CRF

\begin{tabular}{|c|c|c|c|c|c|c|}
\hline \multirow{2}{*}{$\begin{array}{l}\text { Backfill type } \\
\text { rock/tailings }\end{array}$} & \multirow{2}{*}{$\begin{array}{l}\text { Water/cement } \\
\text { ratio }\end{array}$} & \multirow{2}{*}{$\begin{array}{l}\text { Sample } \\
\text { diameter } \\
(\mathrm{mm})\end{array}$} & \multicolumn{2}{|c|}{ Marbles } & \multicolumn{2}{|c|}{ Diorites } \\
\hline & & & $\begin{array}{l}\text { Specific } \\
\text { gravity } \\
\left(\mathbf{g} / \mathbf{c m}^{3}\right)\end{array}$ & $\begin{array}{l}\text { Compressive } \\
\text { strength } \\
\text { (MPa) }\end{array}$ & $\begin{array}{l}\text { Specific } \\
\text { gravity } \\
\left(\mathrm{g} / \mathrm{cm}^{3}\right)\end{array}$ & $\begin{array}{l}\text { Compressive } \\
\text { strength } \\
\text { (MPa) }\end{array}$ \\
\hline $85 / 15$ & 1.30 & 152 & 2552 & 2.502 & 2474 & 2.235 \\
\hline $80 / 20$ & 1.61 & 152 & 2505 & 2.017 & 2443 & 1.460 \\
\hline $70 / 30$ & 2.22 & 152 & 2485 & 1.174 & 2399 & 0.934 \\
\hline $60 / 40$ & 2.83 & 152 & 2400 & 1.058 & 2352 & 0.827 \\
\hline $50 / 50$ & 3.44 & 152 & 2344 & 0.744 & 2314 & 0.708 \\
\hline $30 / 70$ & 4.65 & 152 & 2240 & 0.463 & 2233 & 0.441 \\
\hline $0 / 100$ & 6.48 & 152 & 2132 & 0.255 & 2143 & 0.255 \\
\hline
\end{tabular}

Table 3 shows that under the conditions of cement content of $6 \%$ and a slurry concentration of $72 \%$ in the cemented waste rock filling body, the specific gravity of the filling body decreased gradually with a reduction in the waste rock content, and the specific gravity of the cemented marble rock filling body was a little larger than that of the diorite rock filling body. For the same waste rock-tailings ratio, the compressive strength of the cemented marble rocky fill body was higher than that of the cemented diorites rocky fill, and the difference between the two strengths gradually increased as the waste rock content increased.

\subsubsection{Influence of the muddy waste rock on the backfill strength}

\subsubsection{Experiment content}

Tests on the cemented backfill body strengths of muddy waste rock and clean fine mud-grain waste rock under the same conditions were carried out to analyse and determine the influence of the muddy and finegrain waste rock on the cemented backfill body strength.

\subsubsection{Design of experiment parameters}

The cement content was $6 \%$, the slurry concentration was $72 \%$, and the curing time was $28 \mathrm{~d}$. The design of the mix proportions were as follows. The types of waste rock were marbles and diorites. The muddy waste rock scenarios were naturally muddy and fine-grain waste rock and the non muddy and fine grain waste rock. The rock-tailings ratios were $70 / 30 \%$ and $50 / 50 \%$. The test indicator was the unconfined compressive strength. 


\subsubsection{Results and discussions}

Experiment results are compared in Table 4. The table shows that after removing the mud and fine mud grains from waste rock, the compressive strength of the cemented waste rocky fill body increased under the same conditions, which indicates that the mud and fine-mud grains had an inhibiting effect on the increase in strength provided by the cemented rock-tailings filling body. This is because the cementing agent could adhere to the muddy waste rocks when fine mud adhered to the surface of waste rocks, whereas favourable cementation was not possible for the cemented slurry and waste rock surface, which hindered the cementation effect on the waste rock by the cementing agent.

Table 4 Experimental results for the compressive strength under different conditions of muddy rock

\begin{tabular}{llll}
\hline $\begin{array}{l}\text { Waste Rock } \\
\text { Type }\end{array}$ & $\begin{array}{l}\text { Rock-Tailings } \\
\text { Ratio }\end{array}$ & \multicolumn{2}{l}{ Compressive Strength of Backfill (MPa) } \\
\cline { 3 - 4 } & & $\begin{array}{l}\text { Naturally Muddy } \\
\text { Waste Rock }\end{array}$ & $\begin{array}{l}\text { Non Muddy Waste } \\
\text { Rock }\end{array}$ \\
\hline Marble & $70 / 30 \%$ & 1.17 & 1.21 \\
& $50 / 50 \%$ & 0.74 & 0.79 \\
Diorite & $70 / 30 \%$ & 0.93 & 1.08 \\
& $50 / 50 \%$ & 0.71 & 0.73 \\
\hline
\end{tabular}

\subsection{Relationships between the strength of the cemented backfill and the mix proportions of waste rock, tailings and cement}

\subsubsection{Design of experiment parameter}

The slurry concentration was set at $72 \%$ as an invariant parameter in this experiment, and the curing time was $28 \mathrm{~d}$. The test indicator was the unconfined compressive strength.

Figure 2 shows the distribution of the designed parameters of waste rock content and cement content in the proportioning tests.

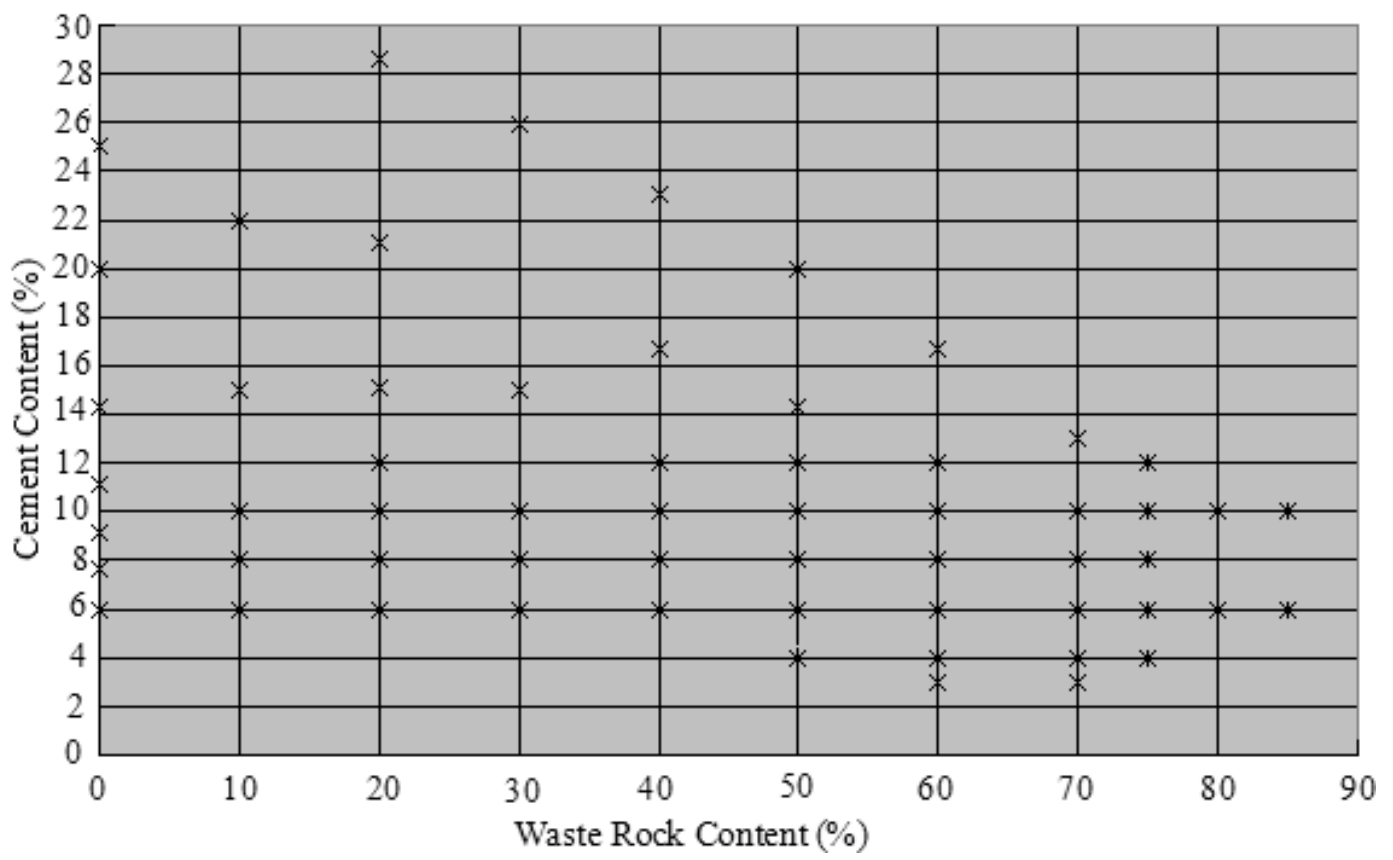

Figure 2 Designed parameters in the cemented waste rock-tailings filling test 


\subsubsection{Results and discussions}

Figure 3 shows that the strength of the cemented backfill body was inhibited by both the cement content and waste rock content, which means an increase in either would enhance the strength of the cemented backfill. If the cement content does not change, the waste rock content can increase, and thus increase the filling body strength if the cement content of the cemented slurry increases to increase the cementation body strength. In addition, with an increase in the waste rock content, the specific surface area of the solid material decreases, and the cement content per unit area increases, and thus the strength of the cementation body increases.

Table 5 compares the strength of the cemented waste rock-tailings filling body with the corresponding strength of the cemented tailings backfill in the cemented backfill under the condition of an invariable tailings to cement ratio. From the data in the table, a diagram comparing the strength of the cemented waste rocky fill and the corresponding strength of the cemented tailings filling body is presented in Figure 4. From the strength curve of the cemented waste rocky fill body under the condition of an invariable tailings to cement ratio, it is seen that the strength of the cemented waste rocky fill body decreased as the waste rock content increased owing to the reduction in the cement content of the filling body. From the strength curve of the cemented tailings backfill, it is seen that the strength of the cemented tailings backfill decreased as the cement content decreased. For the same cement content, the strength of cemented waste rocky fill was higher than that of cemented tailings backfill, and as the waste rock content increased, the rate of the increase in the strength of the cemented waste rocky fill was larger than that of the cemented tailings backfill. In other words, when the cemented rock-tailings slurry was mixed with tailings to replace new waste rock, the strength of the cemented backfill was reduced. Thus, we found that waste rock could improve the strength of cemented backfill effectively.

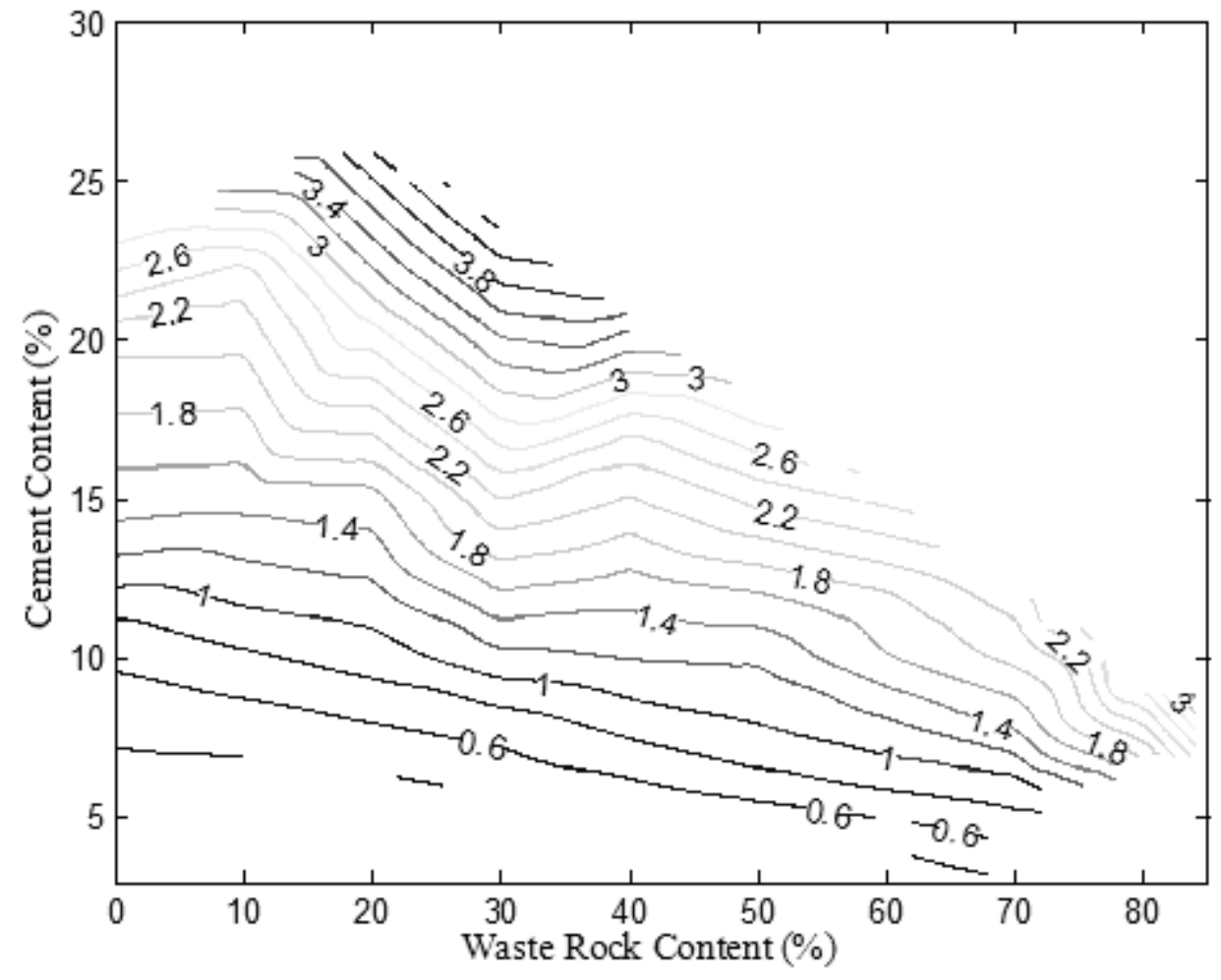

Figure 3 Contour map of the compressive strength of the cemented rock-tailings filling body (cement content of 3-25\%, contour intervals of $0.2 \mathrm{MPa}$ ) 
Table 5 Comparison of the strength of cemented waste rocky fill (tailings-cement ratio of 6) and strength of cemented tailings backfill

\begin{tabular}{|c|c|c|c|c|c|c|c|c|c|}
\hline Waste rock content $(\%)$ & 75 & 70 & 60 & 50 & 40 & 30 & 20 & 10 & 0 \\
\hline $\begin{array}{l}\text { Compressive strength of } \\
\text { cemented rocky fill (MPa) }\end{array}$ & 0.59 & 0.74 & 0.88 & 0.97 & 1.04 & 1.08 & 1.11 & 1.25 & 1.41 \\
\hline $\begin{array}{l}\text { Tailings-cement ratio of } \\
\text { corresponding cemented tailings } \\
\text { backfill }\end{array}$ & 24 & 20 & 15 & 12 & 10 & 8.57 & 7.5 & 6.67 & 6 \\
\hline $\begin{array}{l}\text { Cement content of corresponding } \\
\text { cemented tailings backfill }(\%)\end{array}$ & 4 & 4.76 & 6.25 & 7.69 & 9.09 & 10.45 & 11.76 & 13.04 & 14.3 \\
\hline $\begin{array}{l}\text { Compressive strength of } \\
\text { cemented tailings backfill (MPa) }\end{array}$ & 0.08 & 0.16 & 0.3 & 0.46 & 0.55 & 0.68 & 0.89 & 1.15 & 1.41 \\
\hline
\end{tabular}

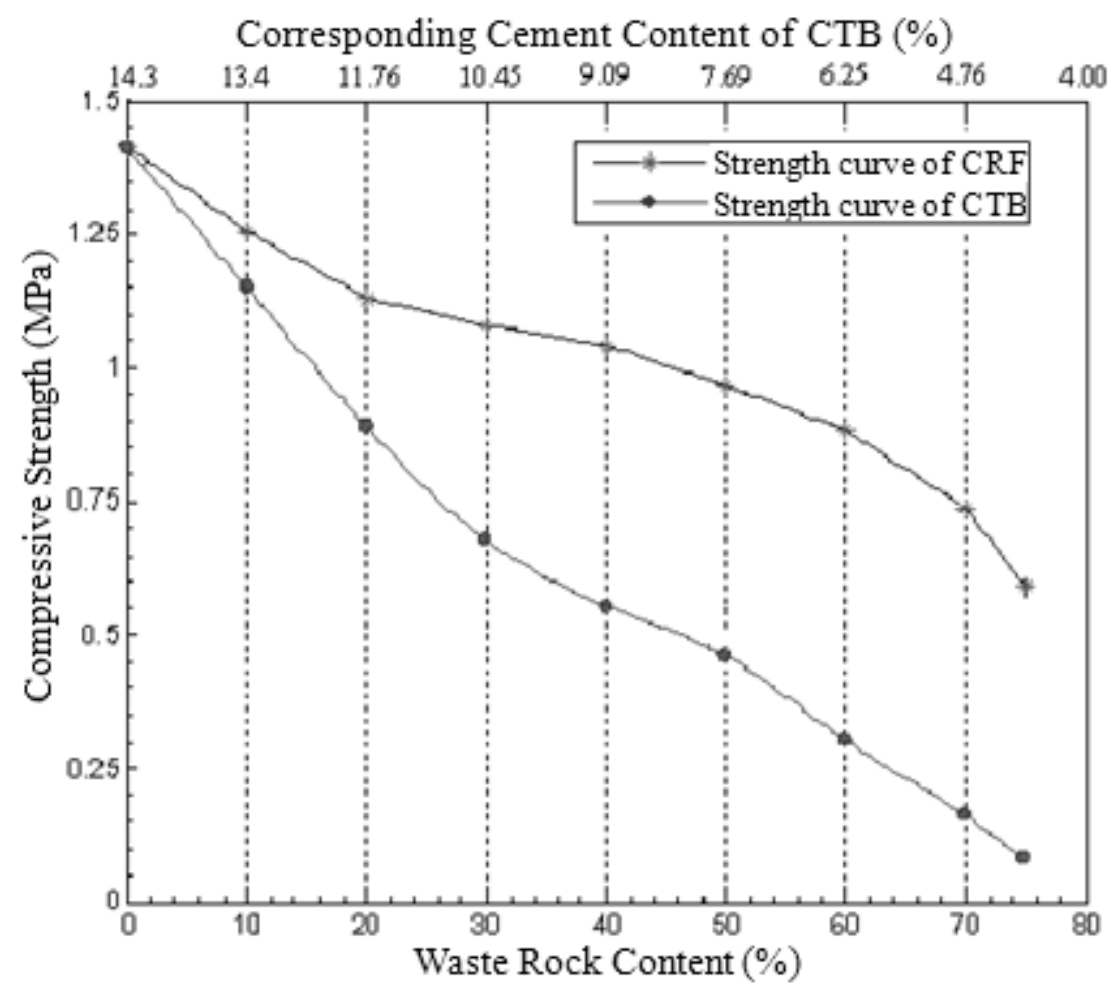

Figure 4 Comparison of the compressive strengths of cemented rocky fill (tailings-cement ratio of 6) and cemented tailings backfill

\subsection{Relationship between the mixed casting method of filling material and the strength of cemented backfill}

Test samples were $152 \mathrm{~mm}$ (diameter) by $305 \mathrm{~mm}$ (height) cylinders, and three filling methods were used during the filling process - even agitation, waste rock input to the slurry, and direct pouring onto waste rock. The different backfill types mainly consisted of cemented waste rock backfill (CRF), cemented tailings encapsulating waste rock column core backfill (CRCB), and cemented tailings backfill (CTB). The CRCB was a cemented tailings waste rock column core encapsulated by a cemented layer with a diameter of $85 \mathrm{~mm}$ and an outer layer of cemented tailings $33.5 \mathrm{~mm}$ thick.

\subsubsection{Mixing methods and backfill methods}

In tests on different mixing methods, the cement content was $6 \%$, the slurry concentration was $72 \%$, the waste rock-tailing ratio was $75 / 25 \%$, and the curing time was $28 \mathrm{~d}$. The waste rock type was diorite, the 
mixing method was even agitation, waste rock was added to the slurry, and the test indicator was unconfined compressive strength.

In tests on different backfill methods, the cement contents were 14 and $8 \%$, the waste rock contents were 0 and $30 \%$, and the slurry concentration was $72 \%$. The backfill types were CRF, CRCB and CTB.

\subsubsection{Results and discussions}

Test results for the compressive strength of the cemented backfill for different filling methods and backfill types are given in Tables 6 and 7.

Table 6 Compressive strengths of the cementation body for different filling methods

\begin{tabular}{llllll}
\hline Mixed Methods & $\begin{array}{l}\text { Cement } \\
\text { Content (\%) }\end{array}$ & $\begin{array}{l}\text { Tailings- } \\
\text { Cement Ratio }\end{array}$ & $\begin{array}{l}\text { Rock- } \\
\text { Tailings Ratio }\end{array}$ & $\begin{array}{l}\text { Specific } \\
\text { Gravity (g/cm }\end{array}$ & $\begin{array}{l}\text { Compressive } \\
\text { Strength (MPa) }\end{array}$ \\
\hline Even agitation & 6 & 4 & $75 / 25 \%$ & 2.446 & 1.25 \\
$\begin{array}{l}\text { Waste rock input to } \\
\text { the slurry }\end{array}$ & 6 & 4 & $75 / 25 \%$ & 2.447 & 1.14 \\
$\begin{array}{l}\text { Pouring directly on } \\
\text { waste rock }\end{array}$ & 6 & 4 & $75 / 25 \%$ & 2.447 & 0.98 \\
\hline
\end{tabular}

Table 6 shows that the compressive strength of cemented backfill was largest for the even agitation of waste rocks and slurry at $1.25 \mathrm{MPa}$, the strength of cemented backfill in the case that waste rock was input to the slurry was the secondary highest at $1.14 \mathrm{MPa}$, and the strength of cemented backfill in the case that slurry was poured directly onto waste rock was the lowest at $0.98 \mathrm{MPa}$. We observed that even agitation enabled the full mixing of the cemented agent slurry and the waste rock, thus allowing good cementation. Mixing waste rock with slurry meant that waste rocks were poured into cemented slurry and cemented by tailings slurry during natural immersion and settlement, and the resulting strength was lower than that obtained with even agitation. This indicates that the slurry cementing of waste rock was not the best cementation process for the mixing. The degree of cementing agent infiltration and cementation effect of the slurry pouring directly on waste rocks are related to the natural accumulation status and gradation of waste rock.

Table 7 Compressive strengths for different cemented backfill types

\begin{tabular}{|c|c|c|c|c|}
\hline Backfill Methods & $\begin{array}{l}\text { Tailings-Cement } \\
\text { Ratio }\end{array}$ & $\begin{array}{l}\text { Waste Rock } \\
\text { Content (\%) }\end{array}$ & $\begin{array}{l}\text { Cement } \\
\text { Content (\%) }\end{array}$ & $\begin{array}{l}\text { Compressive } \\
\text { Strength (Mpa) }\end{array}$ \\
\hline Cemented rocky fill & 6 & 30 & 8 & 0.69 \\
\hline $\begin{array}{l}\text { Cemented tailings } \\
\text { backfill }\end{array}$ & 6 & 0 & 14 & 1.37 \\
\hline $\begin{array}{l}\text { Cemented rock core } \\
\text { backfill }\end{array}$ & 6 & 30 & 8 & 0.62 \\
\hline Cemented rocky fill & 4.3 & 30 & 14 & 1.6 \\
\hline $\begin{array}{l}\text { Cemented tailings } \\
\text { backfill }\end{array}$ & 12 & 0 & 8 & 0.48 \\
\hline
\end{tabular}

Table 7 shows that under the condition of the same cement content of $8 \%$, the strength of CRF was highest at $0.69 \mathrm{MPa}$, that of CRCB was $0.62 \mathrm{MPa}$, and that of CTB was the lowest at $0.48 \mathrm{MPa}$. Under the condition of the same tailings-cement ratio (a ratio of 6), the strength of CTB was $1.37 \mathrm{MPa}$, that of CRF was $0.69 \mathrm{MPa}$, and that of CRCB was $0.62 \mathrm{MPa}$. This can be explained in that under the condition of an invariable tailingscement ratio and waste rock accounting for $30 \%$ of backfill, the cement content in filling materials reduced to 8 from 14\%, which resulted in the strengths of CRF and CRCB being only half that of CTB. The strength of CRCB was a little lower than that of CRF with even agitation. The CRCB process can described as slurry encapsulating loose waste rock, immersing into the loose waste rock column transversally, and producing a 
natural formation of an outer cement tailings layer that encapsulates the cemented waste rock column core body. Because of the smaller transversal infiltration capacity of the cemented slurry, its cemented waste rock column cone degree was poorer. The strength of the cemented backfill was primarily determined by the composite effect of the community formed by the cement tailing layer and waste rock column core.

\section{Conclusions}

Experiments on cemented waste rock-tailings fill showed the following:

- Under the condition of the same waste rock-tailings ratio, the compressive strength of cemented marble rock backfill was higher than that of diorite, and the difference between the two strengths increased gradually with an increase in the waste rock content.

- The relationship between the strength of CRF and the mix proportions of waste rock, tailings and cement showed that the strength of the cemented waste rock-tailings fill was determined by the cement and waste rock contents. The incorporation of waste rock effectively increased the strength of CRF. Under the condition of the same cement content, both CRF and CRCB were stronger than CTB.

- Under the condition of the same backfill strength requirements, the cemented waste rock-tailings filling can reduce cement consumption and reduce on backfill cost.

- The results of the study provide references for the design of the mix proportions of mine fill.

\section{Acknowledgements}

This research was jointly supported by the Opening Project of the Key Laboratory of Solid Waste Treatment and Resource Recycling (SWUST), the Ministry of Education of China (Grant No. 09ZXGK04), and Anqing Copper Mine. The authors gratefully acknowledge Wei Ming and Zou Xian-ji at Anqing Copper Mine for their assistance during the project fieldwork.

\section{References}

Annor, A. (1999) A Study of Characteristics and Behaviour of Composite Backfill Material, McGill University, Montreal, Canada.

Hassani, F. and Razavi, S.M. (2007) A study of physical and mechanical behaviour of gelfill, CIM Bulletin 2(5), pp. 1-7.

Kuganathan, K. (2005) Rock Fill in Mine Fill, Handbook on Mine Fill, Y. Potvin and A.B. Fourie (eds), Australian Centre for Geomechanics, Perth, Australia, 101 p. 
